\title{
Classification of Megathyrsus
} Maximus Accessions Grown in the Colombian Dry Tropical Forest by Nutritional Assessment During Contrasting Seasons

\author{
Juliana Isabel Carvajal-Tapia ${ }^{1 *}$, Johanna Mazabel $^{2}$ and Nelson Jose Vivas-Quila ${ }^{3}$ \\ ${ }^{1}$ National Open and Distance University, CEAD, Popayán, Colombia, ${ }^{2}$ Alliance Bioversity International and CIAT, Cali, \\ Colombia, ${ }^{3}$ Agricultural Nutrition Research Group, NUTRIFACA, School of Agricultural Sciences, University of Cauca, \\ Popayán, Colombia
}

\section{OPEN ACCESS}

Edited by:

Stefan Burkart,

Alliance Bioversity International and

CIAT, France

Reviewed by:

Aníbal Coutinho do Rêgo, Federal Rural University of the

Amazon, Brazi

Jaime Rosero,

University of Antioquia, Colombia

Julián Botero,

Industrial University of

Santander, Colombia

${ }^{*}$ Correspondence: Juliana Isabel Carvajal-Tapia jicarvaja@@unicauca.edu.co; juliana.carvaja@unad.edu.co

Specialty section: This article was submitted to Climate-Smart Food Systems,

a section of the journal

Frontiers in Sustainable Food Systems

Received: 04 May 2021 Accepted: 10 September 2021 Published: 21 October 2021

Citation:

Carvajal-Tapia Jl, Mazabel J and Vivas-Quila NJ (2021) Classification of Megathyrsus Maximus Accessions

Grown in the Colombian Dry Tropical Forest by Nutritional Assessment During Contrasting Seasons. Front. Sustain. Food Syst. 5:684747.

doi: 10.3389/fsufs. 2021.684747
The diversity and use of tropical forages for cattle feeding are the protagonists in livestock systems. The production and nutritional quality of forages represent a strategy of continuous research in animal feeding to help mitigate the environmental impact generated by tropical livestock. The objective of this study was to classify the nutritional behavior in contrasting seasons and the relationship with agronomic traits of a collection of 129 CIAT (Centro Internacional de Agricultura Tropical) accessions of Megathyrsus Maximus established in the Colombian dry tropics. By means of the near-infrared reflectance spectroscopy (NIRS) technique, crude protein (CP), neutral detergent fiber (NDF), acid detergent fiber (ADF), and in vitro dry matter digestibility (IVDMD) were determined under rainy and dry seasons as fixed effects. We measured plant height, dry matter biomass (DMB) and flowering in field. Aspects such as plant height and DMB did not show correlation with nutritional aspects, whereas flowering was correlated with the content of structural carbohydrates. Despite genotype and precipitation affecting nutritional value, there is relative nutritional steadiness in NDF, ADF, and IVDMD between seasons for some accessions. According to the cluster analysis carried out for each season, it was evidenced that from the total collection, 51.2\% of the accessions during the dry season and $19.4 \%$ of the accessions during the rainy season were classified with a better nutritional profile, thus, showing a higher number of materials with better nutritional behavior in the dry season. Both the genotypic characteristics of $M$. maximus and environmental conditions during contrasting seasons are factors that might influence the variability of the nutritional content, productive parameters, and flowering. Additionally, fodder material classification under Hotelling's $T$-squared test and Nutritional Classification Index suggests accessions that might be promising for resilient nutritional quality and adequate DMB, which proves that $M$. maximus could become an alternative for animal feeding and sustainable livestock production during critical dry periods in tropical agroecosystems.

Keywords: forages, grassland, Guinea grass, livestock, Panicum 


\section{INTRODUCTION}

The expansion of the agricultural frontier with crops and pastures in tropical regions of developing countries for food production requires implementing production strategies with an eco-efficient focus to sustainably meet the increasing demand for food (Rao, 2013).

The major part of livestock activity in intertropical regions is carried out under grazing systems and mixed model systems (concentrated pastures), (Gerber et al., 2015). Food for these livestock systems based on pastures is developed through the production of forages, which depends on the rainfall pattern (Castañeda et al., 2015; Gándara et al., 2017; Marcillo et al., 2021), which is influenced by the consequences of climate change. The instability in forage production brings along with it an increase in production costs because of the use of supplements (concentrates), (Morales-Vallecilla and Ortiz-Grisales, 2018) and nutritional variables that influence productivity (Cooke et al., 2020), thus, compromising both cattle feeding efficiency and the sustainable management of herds (Paul et al., 2020).

The diversity and use of tropical forages for livestock feeding are protagonists in tropical livestock systems. Characteristics such as biomass yield and nutritional quality depend on genetics, environment, and some other factors (Paul et al., 2020). Investigating and evaluating these characteristics will contribute to the development of forages adapted to the specific edaphoclimatic conditions of the tropics and identifying genotypes capable of producing "more with less," which, according to Rao (2013), is important for advancing toward an eco-efficient livestock system.

Megathyrsus maximus-Panicum maximum (Cook and Schultze-Kraft, 2015) is an African species that has been widely distributed in the warm areas of Colombia. Under edaphoclimatic conditions of the Colombian dry tropical forest, the response in terms of production is adequate during low-precipitation periods. Also, this grass has short recovery periods, tolerance of shade and moderate drought periods, tolerance of short flooding periods (Morales-Velasco et al., 2016; Matínez-Mamian et al., 2020), and an adequate response in association with forage legumes (Matínez-Mamian et al., 2020) and with silvopastoral systems (Barragán-Hernández and Cajas-Girón, 2019). This grass is promising for environmental management of cattle because of its potential for biological nitrification inhibition (IBN), (Carvajal-Tapia et al., 2021) and is outstanding for its nutritive value, perenniality, and adaptive potential, and for showing diversity among cultivars in terms of yield, forage quality, and response to nutrient fertilization (Benabderrahim and Elfalleh, 2021).

The nutritional quality of $M$. maximus in terms of protein and fiber content, and digestibility, has a wide range of values generated by different edaphoclimatic, genotypic, and management conditions. The attributes of adaptation to edaphoclimatic limitations, forage quality, and seed production facilitate the development of superior cultivars in current grass breeding activities (Rao, 2013). However, identifying the nutritional behavior of the species in a potential livestock area can help to find a versatile feeding alternative for the establishment and development of eco-efficient livestock production or to select material with improved fodder quality (Ramakrishnan et al., 2014).

The nutritional quality and association with the productive parameters of a broad range of accessions of $M$. maximus in Colombian tropical regions have not been described in detail or correlated with climatic factors. This is a relevant aspect in the identification of resilient forage species, particularly for the agricultural sector that faces the consequences of climate change. Therefore, we propose the hypothesis that the rainfall pattern that determines two contrasting seasons (rainy and dry) in tropical regions influences not only the agronomic behavior of the collection of $M$. maximus but also the nutritional composition and at the same time can be related to the productive variables of forages.

NIRS (near-infrared reflectance spectroscopy) is a fast and accurate technique with an eco-friendly technology to diagnose the nutritional quality of tropical forages (International Organization for Standardization ISO 12099:2017., 2017; Parrini et al., 2018; Mazabel et al., 2020). Since 2015, the CIAT forages and animal nutrition quality laboratory has worked on the development of NIRS predictive models, in particular, for neutral detergent fiber (NDF), acid detergent fiber (ADF), crude protein (CP), and in vitro dry matter digestibility (IVDMD) for tropical forages.

With the purpose of helping to identify promising forage crops for tropical areas and to classify potential germplasm for smallholder farmers or plant breeding programs, the object of this study was to classify the vegetative material of M. maximus established in the Colombian dry tropics according to nutritional behavior using NIRS methodology during contrasting seasons and the relationship with plant height, forage production, and flowering with nutritional quality.

\section{MATERIALS AND METHODS}

\section{Location}

The experiment was conducted in a tropical dry forest agroecosystem in the Patía Valley, which is located in the department of Cauca in southwestern Colombia, with an average temperature of $27.9^{\circ} \mathrm{C}$ and bimodal cycle with average annual precipitation of 1,414 mm (Figure 1). To guarantee the process of establishing experimental plots, we used water irrigation and mechanical weed control.

The local soil is a medium-fertility Mollisol. Chemical analysis in the 0 -to $20-\mathrm{cm}$ layer showed $\mathrm{pH}$ of 6.26 , organic matter content of $4.50 \%$, phosphorus content of $6.3 \mathrm{ppm}$, and calcium, magnesium, and potassium content of $14.58,6.91$, and $0.59 \mathrm{cmol} / \mathrm{kg}$, respectively. 1 year after establishment of the experimental plots, we applied fertilizer only once at a rate of $150 \mathrm{~kg} \mathrm{~N} / \mathrm{ha}$ and $95 \mathrm{~kg} \mathrm{P} / \mathrm{ha}$.

\section{Experimental Design in Fields}

For the agronomic and nutritional evaluation in December of 2015, 129 accessions of M. maximus, including commercial varieties provided by the germplasm bank of the International Center for Tropical Agriculture (CIAT) and two improved 


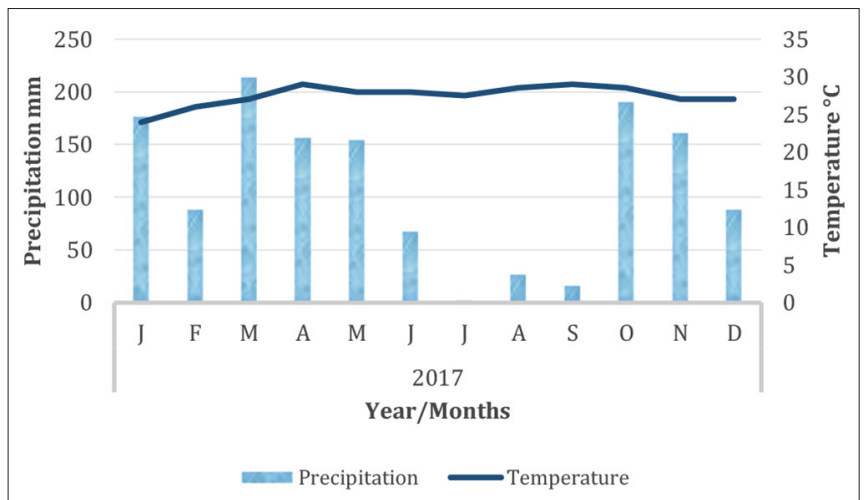

FIGURE 1 | Average temperature values and rainfall accumulation during experiments in field trials. Coordinates: N: $1^{\circ} 59^{\prime} 13^{\prime \prime} ;$ W: $77^{\circ} 5^{\prime} 57^{\prime \prime}$, Patía Valley. Source: NUTRIFACA Weather Station, 2016-2018.

TABLE 1 | Centro internacional de agricultura tropical (CIAT) accession numbers and origin of evaluated Megathyrsus maximus and commercial cultivars.

\begin{tabular}{ll}
\hline Origin & CIAT accessions \\
\hline Kenya & $622,688,691,692,693,6,526,6,536,6,571,6,890$, \\
& $6,891,6,893,6,897,6,898,6,900,6,901,6,903,6,906$, \\
& $6,912,6,915,6,918,6,923,6,981,6,982,6,983,6,984$, \\
& $6,986,6,990,6,996,16,003,16,004$ y 16,005 \\
Tanzania & $6,927,6,928,6,929,6,944,6,945,6,948,6,949,6,951$, \\
& $6,954,6,955,6,960,6,963,6,967,6,968,6,969,6,975$, \\
& $16,011,16,017,16,018,16,019,16,021,16,023$, \\
& $16,025,16,027,16,028,16,034,16,035,16,036$, \\
& $16,038,16,039,16,041,16,044,16,046,16,048$, \\
& $16,049,16,051,16,054,16,055,16,057,16,058$, \\
Unknown & $16,059,16,060,16,061,16,062,16,064,16,065$, \\
& $16,068,16,069 y 16,071$ \\
& $673,685,6,094,6,095,6,171,6,175,6,461,6,497$, \\
& $6,500,6,501,6,525,6,658,6,784,6,787,6,796,6,799$, \\
& $6,805,6,831,6,836,6,837,6,839,6,840,6,842,6,843$, \\
& $6,855,6,857,6,864,6,866,6,868,26,723,26,906$, \\
Ivory Coast & $26,911,26,917,26,923,26,924,26,925,26,936$, \\
Rwanda & $26,937,26,939,26,942,26,944$ y 26,947 \\
Commercial & 6,872 \\
& 26,360 \\
\hline & 6,962 Mombasa, 6,826 Coloniao, 16,031 Tanzania, \\
& 6,299 Tobiatá, 26,900 Vencedor y Massai \\
\hline
\end{tabular}

Urochloa species (U. brizantha cv. Toledo and hybrid cv. Cayman) as controls (Table 1), were established in plots using a randomized complete block design with three replications. The experimental units (plots) measured $4 \mathrm{~m}^{2}$, and the plants had 1012 tillers. The distance between plots was $1 \mathrm{~m}$, and the distance between blocks was $2 \mathrm{~m}$ (Figure 2).

To determine the number of regrowing days and provide homogeneous conditions for all accessions, a standardization cut was applied. It was a mechanical cutting of plots at a residual height of $30 \mathrm{~cm}$ above the soil. Seasonal conditions in the field area and harvesting age are shown in Table 2.

We measured (a) plant height according to the methodology of Toledo and Schultze-Kraft (1982) and (b) flowering (FW). We used observations and calculated the percentage of flowering present in the experimental plot in a range of $0-100 \%$ at the time of evaluation. For dry matter biomass (DMB), we estimated the availability of green forage (GF) after cutting at the height of $30 \mathrm{~cm}$ from the ground and measuring the weight per plot in the field. Out of all the GF, we weighed subsamples of $\sim 200 \mathrm{~g}$. These were dried in an oven with controlled ventilation at a temperature of $60^{\circ} \mathrm{C}\left(140^{\circ} \mathrm{F}\right)$ until reaching constant weight $(48$ to $72 \mathrm{~h})$. With the final weight of the subsamples, we estimated dry matter.

\section{Near-Infrared Reflectance Spectroscopy Testing in the Laboratory}

The subsamples obtained in the field to determine DMB were analyzed in the CIAT forages and animal nutrition quality laboratory, where they were pulverized using a Retsch SM 100 (Retsch GmbH, Haan, Germany) with a 1-mm bottom screen. For NIRS processing, we used a Foss 6,500 model and ISIS software (IS-2,250) version 2.71 (FOSS and Infrasoft International, USA, 2005). For each sample, duplicates of the spectra were taken in separate quartz cells of $3.5-\mathrm{cm}$ internal diameter and $1-\mathrm{cm}$ thick. The wavelength range was from 400 to $2,500 \mathrm{~nm}$.

The values obtained through wet chemistry were used to build chemo metric models (Mazabel et al., 2020) and generate predictive equations in NIRS. Chemical analyses were performed in duplicate for each accession in both seasons (rainy and dry) under the guidelines of the 21st edition of the Official Methods of Analysis of (AOAC International, 2002). Crude protein content was determined using the FOSS Kjeltec ${ }^{\mathrm{TM}} 8,100$ (Foss Company, HillerØed, Denmark). An ANKOM 2,000 fiber analyzer (ANKOM Technology Corporation, Macedon, NY, USA) was used for NDF and ADF (Van Soest et al., 1991) and for IVDMD (Tilley and Terry, 1963).

The results of the reference chemical analysis and the spectral signals of each sample were processed using Win ISI software version 4.0. Then, the results were incorporated in equations generated at the CIAT forages and animal nutrition quality laboratory, as follows: $\mathrm{R}^{2}$ of $0.93,0.98,0.85$, and 0.98 and standard error for cross validation (SECV) of 2.11, 1.22, 2.78, and 0.61 for NDF, ADF, IVDMD, and CP, respectively (Molano et al., 2016). This increases the action range and accuracy of the model.

\section{Data Analysis}

Descriptive statistics and Pearson correlation coefficient for every season were obtained with SAS Statistical Software (Statistical Analysis System) version 9.4 (2018) (SAS, 2016). Figure of correlation was obtained with package corrplot in $\mathrm{R}$ (Wei and Simko, 2017). Cluster analysis was used, and principal components were calculated using the library "FactoMineR" and package "Factoextra" (Kassambara and Mundt, 2020) with the variables NDF, ADF, CP, and IVDMD for every season. Figures were created in R using the package "ggplot2" (Wickham, 2016). Wilcoxon sum rank test was used to compare differences between means in terms of the season for each of the variables in $\mathrm{R}$ version 4.0.3 (R Core Team, 2020).

To find a classification index for the fodder material according to nutritional content, multicriteria weighted indices were adapted (Contreras et al., 2004). To obtain a level 


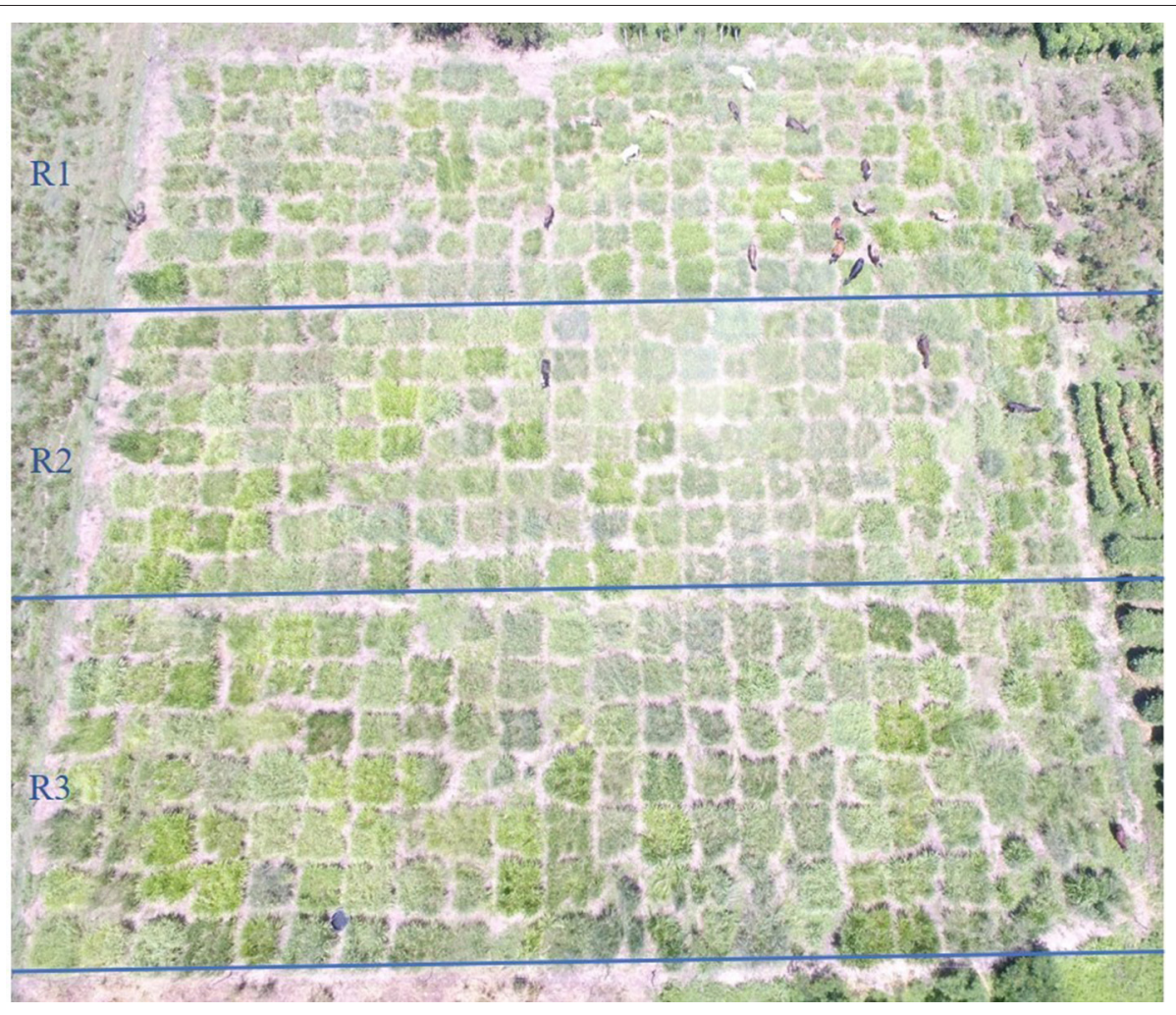

FIGURE 2 | Aerial view of the field experimental design. R, replications.

TABLE 2 | Seasonal conditions and plant harvesting parameters for agronomy and nutritional evaluation in the Patía Valley, Cauca, Colombia.

\begin{tabular}{|c|c|c|c|c|c|c|c|c|}
\hline \multirow[t]{2}{*}{ Season } & \multicolumn{2}{|c|}{ Plant harvesting parameter } & \multirow[t]{2}{*}{$\begin{array}{l}\text { Period of evaluation } \\
\text { from }\end{array}$} & \multicolumn{2}{|c|}{ Temperature $\left({ }^{\circ} \mathrm{C}\right)$} & \multicolumn{2}{|c|}{$\begin{array}{c}\text { Humidity } \\
\text { average \% }\end{array}$} & \multirow[t]{2}{*}{$\begin{array}{c}\text { Total } \\
\text { precipitation }(\mathrm{mm})\end{array}$} \\
\hline & Regrowing & Average height $(\mathrm{cm})$ & & Minimum & Maximum & Average & Average & \\
\hline Rainy & 6 weeks or 41 days & 130.7 & March 24 to May 4, 2017 & 21.5 & 31.8 & 26.7 & 77 & 172.1 \\
\hline Dry & 8 weeks or 55 days & 55.2 & June 30 to August 24, 2017 & 19.6 & 36.1 & 27.8 & 61.7 & 22.8 \\
\hline
\end{tabular}

of classification, a value was assigned to each variable considering the relative importance with regard to nutritional assessment of $\mathrm{CP}, \mathrm{NDF}, \mathrm{ADF}$, and IVDMD in consumption, use, and rumen degradability-diet composition (Van Soest, 1982; Barahona-Rosales and Sánchez-Pinzón, 2005). The Nutritional Classification Index was calculated as follows:

$\mathrm{NCI}=\left(\operatorname{IVDMD~R} * 8+\mathrm{IVDMD} \mathrm{D}^{*} 7+\mathrm{CP} \mathrm{R} * 6+\mathrm{CP} \mathrm{D}^{*} 5\right.$ $\left.+\mathrm{NDF} \mathrm{R}^{*} 4+\mathrm{NDF} \mathrm{D}^{*} 3+\mathrm{ADFR}^{*} 2+\mathrm{ADF} \mathrm{D}^{*} 1\right) / 8$,

where NCI is the Nutritional Classification Index, IVDMD R is the in vitro dry matter digestibility rainy season, IVDMD D is the IVDMD dry season, CP R, is the crude protein rainy season, $\mathrm{CP} \mathrm{D}$ is the CP dry season, NDF R is the neutral detergent fiber rainy season, NDF D is the NDF dry season, $A D F R$ is the acid detergent fiber rainy season, and ADF D is the ADF dry season.

To select accessions without significant changes in nutritional composition in the evaluation from one season to the next, the Hotelling $T$-squared test was performed using the Hotelling library and package corpcor in R (Schafer et al., 2017).

\section{RESULTS}

The contrasting seasons present in the Colombian dry tropics might explain the differences found in this research regarding the agronomic and nutritional behavior of M. maximus. Flowering, plant height, BDM, and $\mathrm{CP}$ decreased during the dry season compared with the rainy season at $64.8,57.8,43.1$, and $27.7 \%$, respectively (Table 3 ). Low precipitation, the lowest relative humidity, and the highest temperature (Table 2) were determining factors for the changes observed mainly in the agronomic variables. The average NDF, ADF, and IVDMD contents of the M. maximus collection differ from 1 to $2 \%$ from one season to the other. The Wilcoxon test for comparison of means indicates statistical differences when the accessions are under different rainfall conditions (Table 3).

Commercial cultivars of $M$. maximus show a similar nutritional behavior as the rest of the studied collection. During the dry season, NDF content increased slightly except in 
TABLE 3 | Descriptive statistics and significance between seasons of the nutritional composition and agronomic traits of a collection of Megathyrsus maximus in Colombian dry tropical.

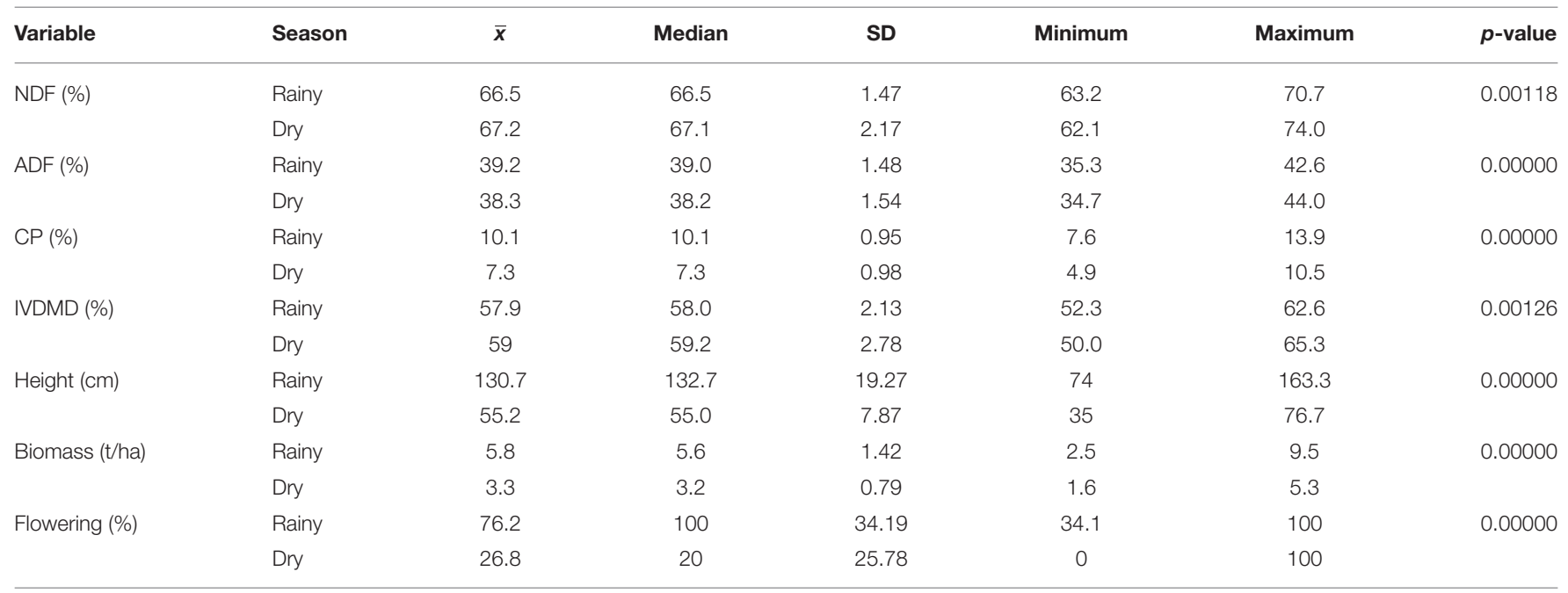

NDF, neutral detergent fiber; $A D F$, acid detergent fiber; $C P$, crude protein; IVDDM, in vitro digestibility of dry matter.

Mombasa, Massai, and Coloniao. In contrast, ADF content decreased, except in Tanzania. Tanzania shows higher CP content and the lowest NDF y ADF content during the rainy season. Mombasa and Coloniao stand out for featuring the lowest NDF and ADF content during the dry season. Vencedor and Coloniao showed high IVDMD during the rainy season and Mombasa in the dry season (Figure 3).

Analysis using Pearson's correlation coefficient shows that different degrees of associativity exist, highlighting values highly significant and superior $(r \geq 0.3)$. Among the agronomic measurements, plant height is directly related to DMB in a positive manner ( $r=0.41$ and 0.48 , rainy and dry season, respectively), whereas with flowering, it is related in a negative manner in the rainy season $(r=0.39)$. This could be interpreted as a high forage yield being estimated for the tall accessions in the rainy season during 42 days, and not presenting flowering or having low flowering upon finalizing the cutting period.

The positive relationship existing between flowering and structural carbohydrate content is evidenced in the two seasons. This suggests that physiological traits such as flowering could have a stronger relationship with the nutritional parameters in the $M$. maximus collection under the edaphoclimatic conditions of the Colombian dry tropical forest. Likewise, in Figure 4, a higher degree of associativity is noted among the traits estimated in the nutritional evaluation.

In both seasons, the structural carbohydrate content of $M$. maximus influenced $\mathrm{CP}$ content in a negative manner. The correlation is higher for ADF content.

In the rainy season, $\mathrm{ADF}(r=0.65)$ shows a moderate and negative correlation with IVDMD, higher than when we refer to $\mathrm{NDF}(r=0.49)$. NDF and ADF have an evident positive correlation, resulting from the use of NDF content in the ADF calculation (Figure 4).
For the cluster analysis, three clusters $(\mathrm{Cl})$ were defined (Table 4 and Figure 5) considering the degree of resemblance in specific characteristics of the accessions for each cluster. For both seasons, the best nutritional composition corresponds to accessions of $\mathrm{Cl} \mathrm{1;} \mathrm{some} \mathrm{accessions} \mathrm{and} \mathrm{material} \mathrm{of} \mathrm{genus}$ Urochloa have lower NDF and ADF and higher $\mathrm{CP}$ and IVDMD, contrary to what $\mathrm{Cl} 3$ shows, with accessions having lower nutritional content with higher NDF and ADF and lower $\mathrm{CP}$. $\mathrm{Cl} 2$ materials are characterized by having an intermediate composition between $\mathrm{Cl} 1$ and $\mathrm{Cl} 3$ (Tables 4,5 ). In dry and rainy seasons, 51.2 and $19.4 \%$ of the collection, respectively, stands out for its nutritional profile. Therefore, a higher number of accessions have a great nutritional profile during the dry season in the tropics and are available for further study.

The distribution of the clusters (Figure 5) shows the description of the correlations and the different nutritional behavior from Megathyrsus and Urochloa species, during both seasons. Also, during the rainy season, the response of Tanzania stands out.

In each season, the following accessions stand out for being part of the $41.9 \%$ of the collection with DMB above average at 5.9 and $3.4 \mathrm{t} /$ ha in the rainy and dry season, respectively, and being classified in the cluster with the best nutritional profile $(\mathrm{Cl})$.

In the rainy season, accessions CIAT 6,501, 6,842, 6,868, $16,004,16,023,16,048,16,062,16,071$, and 26,723 stand out; in the dry season, accessions CIAT 693, 6,171, 6,497, 6,658, 6,836, $6,891,6,898,6,903,16,005,16,011,16,025,16,027,16,034,16,035$, $16,036,16,038,16,039,16,044,16,049,16,058,16,059,26,936$, 26,937 and Massai stand out.

For the NCI, the highest indices correspond to accessions 685 (199.05) and 6,864 (197.30), belonging to Cl1 in both seasons. Accession CIAT 26,911 had one of the highest values for NDF, also standing out for its value in NCI (198.91).

On the other hand, Hotelling's multivariate $T$-squared test showed that accessions 6,968, 26,360, and 26,947 did not feature 


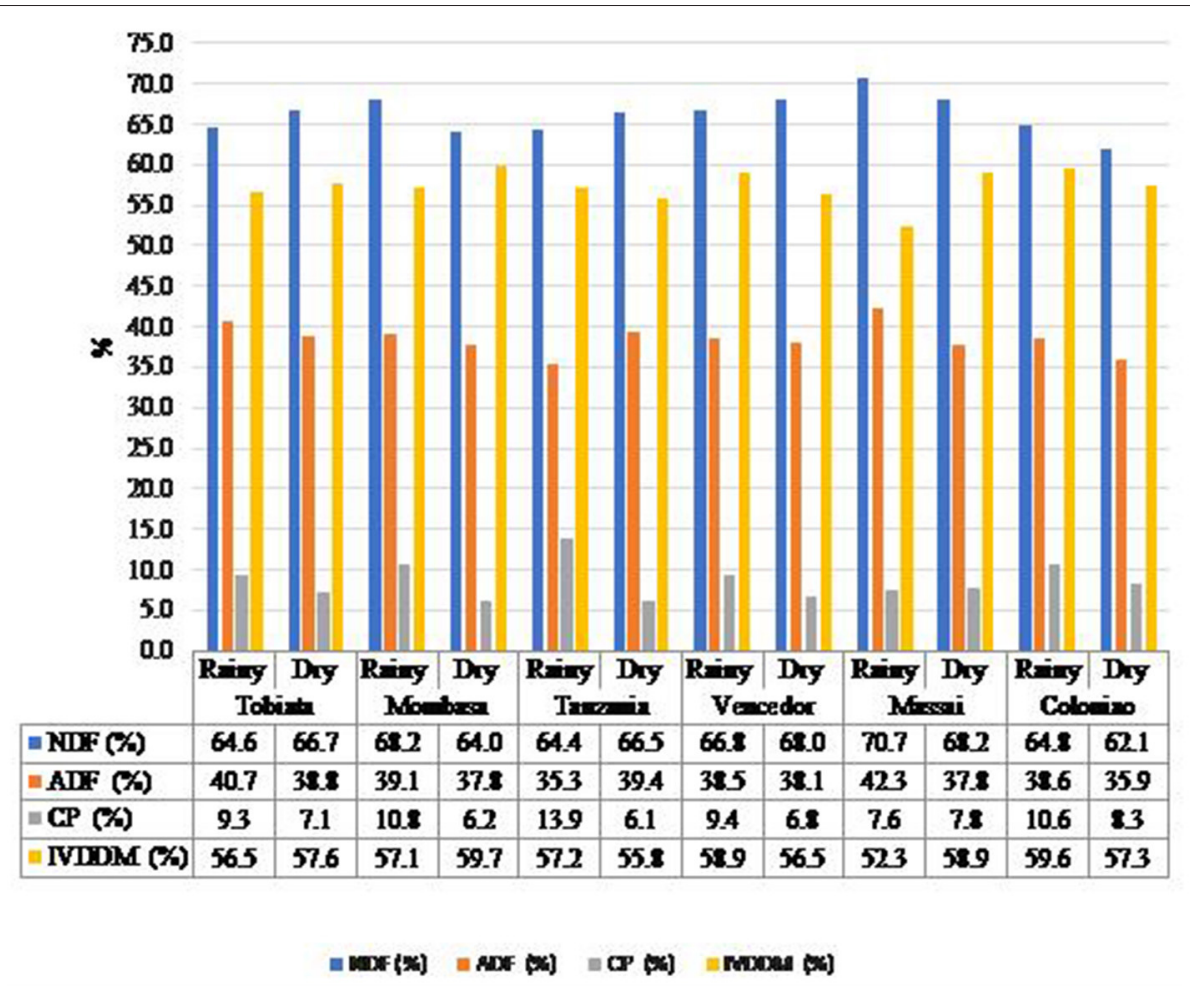

FIGURE 3 | Comparative analysis between commercial cultivars of Megathyrsus maximus in terms of CP, crude protein; NDF, neutral detergent fiber; ADF, acid detergent fiber; IVDMD, in vitro dry matter digestibility.

significant changes from the rainy to dry season in NDF, ADF, CP, and IVDMD, and their NCI surpassed 189.94.

\section{Discussion}

Edaphoclimatic stress factors are abiotic indicators that become important in the search for forage material adapted for intensive production in a sustainable manner (Rao, 2013). In the Patía Valley region, a representative dry tropical agroecosystem, the evaluations set up in this research during contrasting seasons allowed us to compare the agronomic and nutritional behavior of a collection of $M$. maximus, helping to identify physiological mechanisms and the association of flowering with nutritional traits, which contributes to the selection of interesting traits. This provides tools so that breeding programs can broaden their research when seeking forage material resilient to climate change.

Plant height, flowering, $\mathrm{DMB}$ and crude protein of the collection were higher during the rainy season, contrasting with stress, growth, and production limitations during the dry season (Hare et al., 2015), which indicates that the water supply favors agronomic characteristics and protein content (Larsen et al., 2021). Weather characteristics have an effect on agronomic and nutritional parameters for M. maximus (Machado, 2013; Lemos et al., 2017; Maranhão et al., 2021; Marcillo et al., 2021).

\section{Productive Measurements and Flowering}

The mean values for plant height and DMB reached by the $M$. maximus germplasm were similar and superior to those registered in other tropical regions (Machado, 2013; Benabderrahim and Elfalleh, 2021), with fertilization (Braz et al., 2017) or higher rainfall (Macedo et al., 2017).

Studies with commercial varieties suggest that, at 70-to 90$\mathrm{cm}$ height, a higher quantity of biomass is generated with adequate grassland recovery for the next grazing (Soares Filho et al., 2015; Carvalho et al., 2017). In the rainy season, the entire collection reached the mínimum value of the range; whereas, in the dry season, this was obtained only by accessions $16,035,691,6,982,6,960$, and 6,915 (Supplementary Material). For DMB, an important variable for adoption processes by farmers in tropical countries (Mwendia et al., 2019), the mean and maximum values (5.8 and $9.5 \mathrm{t} / \mathrm{ha}$, respectively) of the collection during the rainy season were similar to those reported in previous studies in the same zone with commercial cultivars (6.3 and 9.8 t/ha, every 45 days) (Vivas-Quila et al., 2015). In spite of the dry season, the average and maximum values of DMB declined notably ( 3.3 and $5.3 \mathrm{t} / \mathrm{ha}$, respectively). The values obtained were also higher than those obtained with naturalized species in the Patía Valley region, and in different tropical regions such as Brazil (Macedo et al., 2017) and Cuba (Machado, 2013). These values were improved only in Thailand with nitrogen fertilization (Hare et al., 2015). In addition, the positive correlation between plant height and DMB (Figure 4) might indicate that the evaluated collection presents adequate DMB yield under the edaphoclimatic conditions of the Patía Valley. 


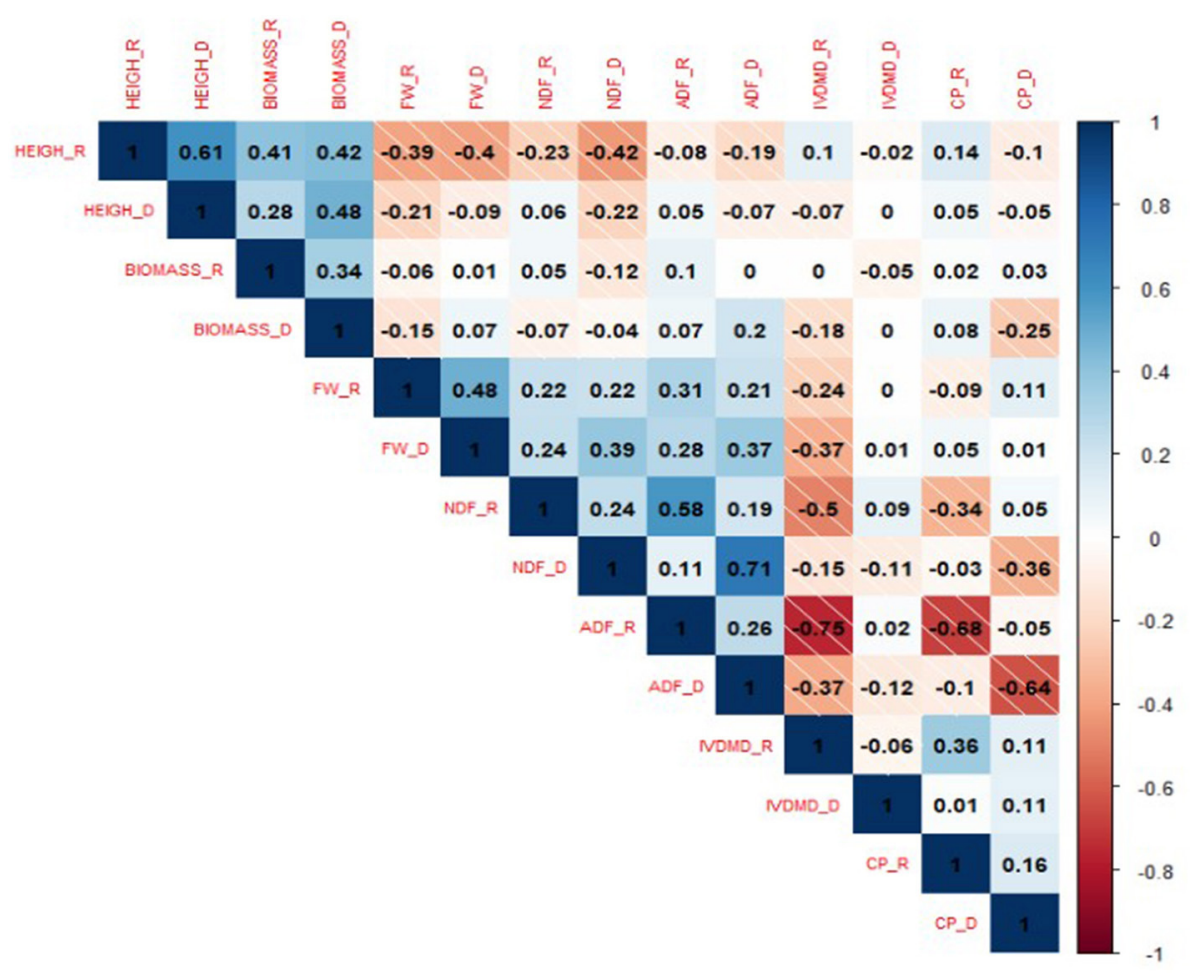

FIGURE 4 | Correlograms with Pearson coefficient to visualize correlation among agronomic and nutritional variables of the Megathyrsus maximus collection in the Patía Valley of Colombia. BIOMASS_R, biomassa dry matter in rainy season; BIOMASS_D, biomassa dry matter in dry season; Heigh_R, in rainy season; Heigh_D, in dry season; FW_R, flowering in rainy season; FW_D, flowering in dry season; NDF_R, neutral detergent fiber in rainy season; NDF_D, neutral detergent fiber in dry season; ADF_R, acid detergent fiber in rainy season; ADF_D, acid detergent fiber in dry season; CP_R, crude protein in rainy season; CP_R, in dry season; IVDMD_R, in vitro dry matter digestibility in rainy season; IVDMD_D, in vitro dry matter digestibility in dry season.

TABLE 4 | Nutritional behavior per cluster in a Megathyrsus maximus collection during rainy and dry seasons in Colombian dry tropical forests.

\begin{tabular}{|c|c|c|c|c|c|c|c|c|c|c|}
\hline Cluster & \multicolumn{2}{|c|}{ Number of accessions } & \multicolumn{2}{|c|}{ NDF (\%) } & \multicolumn{2}{|c|}{ ADF (\%) } & \multicolumn{2}{|c|}{ CP (\%) } & \multicolumn{2}{|c|}{ IVDMD (\%) } \\
\hline 2 & 55 & 30 & $66.6 \pm 1.3 \mathrm{~b}$ & $67.4 \pm 1.8 \mathrm{~b}$ & $38.6 \pm 0.7 b$ & $38.6 \pm 1.0 \mathrm{~b}$ & $10.0 \pm 0.7 b$ & $7.1 \pm 0.6 b$ & $59.0 \pm 1.0 b$ & $55.9 \pm 1.9 c$ \\
\hline 3 & 51 & 35 & $67.4 \pm 1.1 a$ & $69.5 \pm 1.9 a$ & $40.6 \pm 0.8 a$ & $40.2 \pm 1.3 a$ & $9.5 \pm 06 c$ & $6.4 \pm 0.6 c$ & $55.8 \pm 1.3 \mathrm{c}$ & $60.0 \pm 1.9 b$ \\
\hline
\end{tabular}

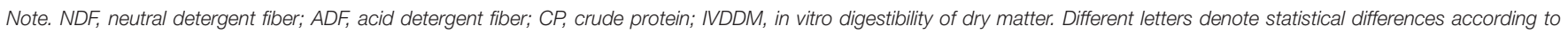
analysis of variance and Tukey HSD test $(\alpha=0.05)$.

Megathyrsus maximus is usually described as drought resistant (Rodríguez et al., 2017) with adaptation to varied edaphoclimatic conditions because of its clumps and strong root system (Kissmann and Groth, 1995; Benabderrahim and Elfalleh, 2021). However, it expresses its productive potential during the rainy season. Under the edaphoclimatic conditions of the Patía Valley and during the rainy period, it is possible to consider a recovery period of about 35 days, and it is advised to consider irrigation during the dry season to reach the potential of the species.

Flowering is a determining variable for plant breeding technology adoption processes. It is related to forage yield (Casler et al., 2018; Casler, 2019). Flowering determines nutritional composition (Gusha et al., 2019), specifically in this research with
$\mathrm{NDF}$ and ADF content and persistency in the field. Light intensity might also affect flowering (Tavares de Castro and Carvalho, 2000). During the dry season, no flowering occurred, or it was lower than 10\% for accessions: $622,688,693,6,094,6,175,6,299$ Tobiatá, 6,497, 6,500, 6,525, 6,658, 6,796, 6,837, 6,857, 6,868, 6,897, 6,901, 6,906, 6,918, 6,923, 6,927, 6,928, 6,948, 6,962, 6,963, $6,968,16,003,16,017,16,023,16,027,16,028,16,034,16,035$, $16,036,16,038,16,039,16,048,16,049,16,051,16,055,16,061$, $16,062,16,069,16,071,26,360,26,900$ vencedor, $26,906,26,923$, $26,924,26,925,26,937$, and 26,939 (39.5\% of the collection), and during the rainy season for accessions 6,299 Tobiatá, 6,962 Mambasa, 6,963, 16,027, 16,028, 16,035, 16,044, 16,051, 16,061, $16,069,16,071,26,723$, and 26,925. 


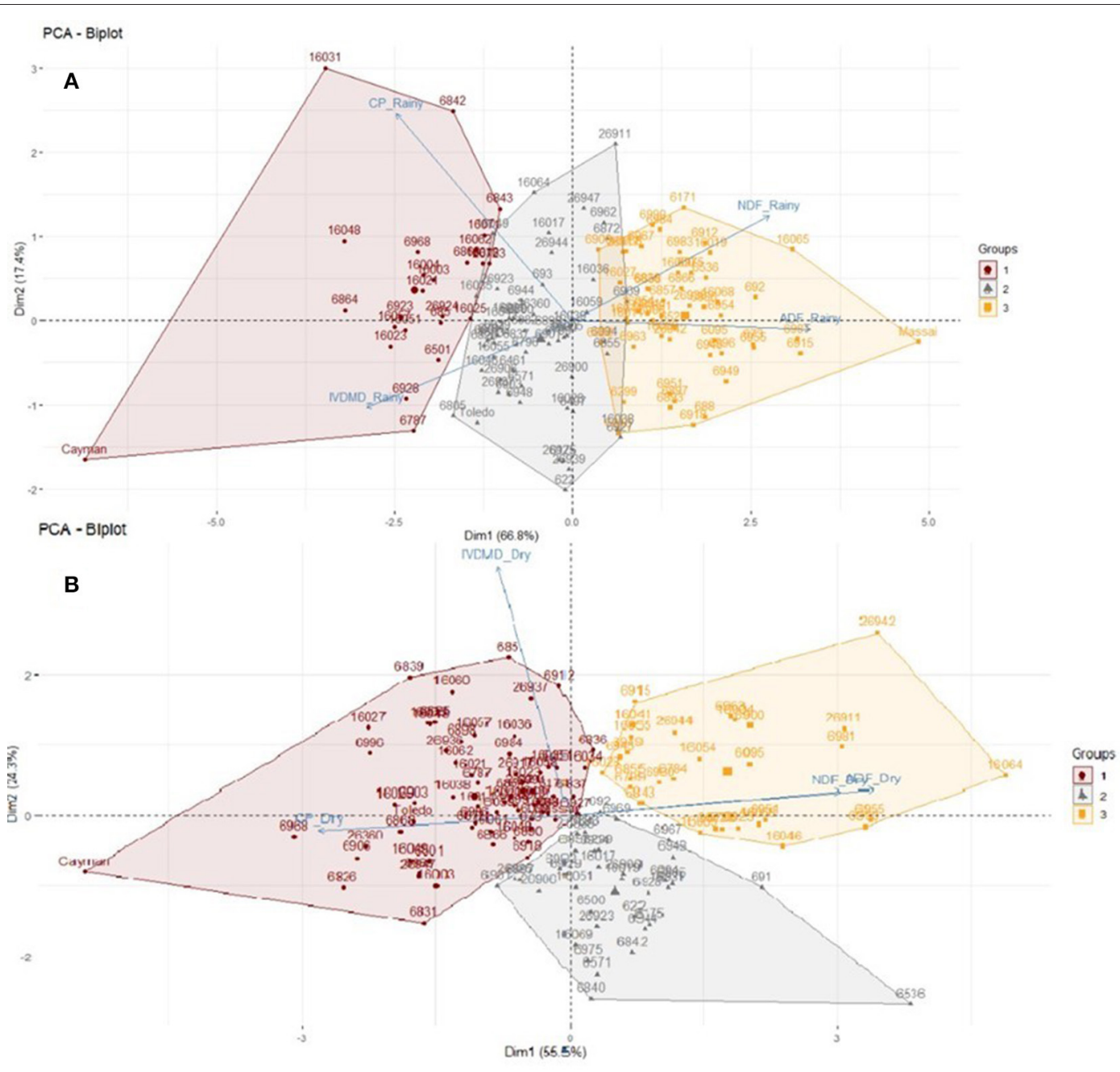

FIGURE 5 | Cluster analysis based on principal components of the germplasm collection of Megathyrsus maximus. Cumulative variance accounts for 86 and $80 \%$ for the rainy and dry season, respectively. ADF, acid detergent fiber; CP, crude protein; IVDMD, in vitro dry matter digestibility; NDF, neutral detergent fiber. (A) Rainy season. (B) Dry season.

Flowering was the variable that declined the most when it was evaluated in the dry season vis-à-vis the rainy season. Lower flowering in germplasm during the dry season despite better light conditions in the tropics could be associated with hydric stress (Wilson and Ng, 1975) and high evaporation, with the possibility that this could generate a negative hydric balance for forage production and the production process of grasses (Rao, 2013). According to (Atencio Solano et al., 2018), there is an evident effect of the dry season on vegetative development, which influences flowering of the species. This matches the negative correlation between flowering and plant height in the rainy season $(r=0.39)$.

\section{Nutritional Composition}

Factors such as management, regrowth age, fertilization, cut height, phonological aspects, growth under shade, and season might have a significant effect on the nutritional value of forages
(Van Soest, 1982; Velásquez et al., 2010; Santiago-Hernández et al., 2016; de Vasconcelos et al., 2019; Schnellmann et al., 2020; Tesk et al., 2020), which affects digestibility in animals (Valente et al., 2010). Variability in structural carbohydrates (NDF, ADF) in the M. maximus collection might be influenced by characteristics related to the accessions' own physiological and metabolic aspects such as the conversion efficiency of nitrogen and flowering rate (dos Costa et al., 2017), which might generate a wide range of available accessions and could be used in plant breeding programs (Deo et al., 2020) to produce or select materials with the best IVDMD (Barahona-Rosales and SánchezPinzón, 2005).

The protein content decline during low precipitation periods, similar to that found by Larsen et al. (2021), might be caused by the lack of production of new leaves and tillers. Also, the senescent material decreases cellular content, in particular, protein (Vargas Junior et al., 2013). M. maximus shows a higher protein content during the rainy season and under shady 
TABLE 5 | Grouping of the M. maximus collection by nutritional behavior in rainy and dry seasons of the Patía Valley, Cauca, Colombia.

\begin{tabular}{|c|c|}
\hline Season & Cluster 1 \\
\hline Rainy & $\begin{array}{l}\text { 685, 6,501, 6,787, 6842, 6,843, 6,864, 6,868, 6923, } \\
\text { 6,928, 6,968, 16,003, 16,004, 16,018, 16,021, 16,023, } \\
\text { 16,025, 16,031, 16,048, 16,051, 16,057, 16,062, } \\
\text { 16,071, 26,723, 26,924 and Urochloa hibrido cv } \\
\text { Cayman }\end{array}$ \\
\hline \multirow[t]{2}{*}{ Dry } & $\begin{array}{l}673,685,688,693,6,171,6,461,6,497,6,501,6525, \\
6,658,6,787,6,826,6,831,6,836,6,837,6,839,6,864, \\
6,866,6,868,6,872,6,890,6,891,6,898,6903,6,906, \\
6,912,6,918,6,927,6,962,6,968,6,983,6,984,6,986, \\
6996,16,003,16,005,16,011,16,018,16,021,16,023, \\
16,025,16,027,16,034,16,035,16,036,16,038, \\
\text { 16,039, 16,044, 16,048, 16,049, 16,057, 16,058, } \\
\text { 16,059, 16,060, 16,061, 16,062, 16,071, 26,360, } \\
26,917,26,924,26,936,26,937,26,947, \text { Massai, } \\
\text { Urochloa brizantha cv toledo and Urochloa hibrido cv } \\
\text { Cayman }\end{array}$ \\
\hline & Cluster 2 \\
\hline Rainy & $\begin{array}{l}622,693,6,094,6,175,6461,6,497,6,500,6,571 \\
6,784,6,796,6,799,6,805,6,826,6,831,6,837,6,839, \\
6,855,6,872,6,890,6,901,6,903,6,927,6,929,6,944, \\
6,948,6,960,6,962,6,969,6,982,16,005,16,017 \\
\text { 16,028, 16,034, 16,035, 16,036, 16,038, 16,039, } \\
\text { 16,044, 16,046, 16,049, 16,055, 16,059, 16,061, } \\
\text { 16,064, 26,360, 26,900, 26,906, 26,911, 26,923, } \\
\text { 26,925, 26,937, 26,939, 26,944, 26,947 and Urochloa } \\
\text { brizantha cv toledo }\end{array}$ \\
\hline \multirow[t]{2}{*}{ Dry } & $\begin{array}{l}622,691,692,6,094,6,175,6,299,6,500,6,536, \\
6,571,6,805,6,840,6,842,6,857,6,893,6,897,6,901 \\
6,928,6,929,6,944,6,948,6,954,6,967,6,969,6,975 \\
6,982,16,017,16,019,16,031,16,051,16,069,26,900 \\
26,906,26,923,26,925 \text { and 26,939 }\end{array}$ \\
\hline & Cluster 3 \\
\hline Rainy & $\begin{array}{l}\text { 673, 688, 691, 692, 6,095, 6,171, 6,299, 6,525, 6,536, } \\
6,658,6,836,6,840,6,857,6,866,6,891,6,893,6,897 \\
6,898,6,900,6,906,6,912,6,915,6,918,6,945,6,949 \\
6,951,6,954,6,955,6,963,6,967,6,975,6,981,6,983 \\
6,984,6,986,6,990,6,996,16,011,16,019,16,027 \\
16,041,16,054,16,058,16,060,16,065,16,068 \\
16,069,26,917,26,936,26,942 \text { and Massai }\end{array}$ \\
\hline Dry & $\begin{array}{l}6,095,6,784,6,796,6,799,6,843,6,855,6,900,6,915 \\
6,923,6,945,6,949,6,951,6,955,6,960,6,963,6,981 \\
6,990,16,004,16,028,16,041,16,046,16,054,16,055 \\
16,064,16,065,16,068,26,723,26,911,26,942 \text { and } \\
26,944\end{array}$ \\
\hline
\end{tabular}

conditions (Dele et al., 2017; Barragán-Hernández and CajasGirón, 2019). In contrast, other authors argue that higher values for protein can be found during the dry season (Rodríguez et al., 2017).

The preservation of beef cattle is an important goal in the Patía Valley region, where animals lose weight and mortality increases because of the lack of water and good-quality feed. Considering the challenging hydric conditions of the tropical zone during the dry season, the average protein content of $7.3 \%$ and the maximum of $10.5 \%$ in $M$. maximus stand out. These nutritional values contribute to preserving rumen functionality. A relevant consideration to keep a functional rumen in bovines is the minimum required nitrogen amount equivalent to $8 \%$ of CP (Gaviria et al., 2015). Also, considering that in this region most of the plants for a complementary diet are grasses, fodder legumes, and other plants rich in protein, the contribution of $M$. maximus could be ideal to avoid a loss of rumen functionality and to support livestock production during the dry season.

A high negative correlation exists between structural carbohydrate content and digestibility (Jung et al., 1997) in the $M$. maximus collection in the rainy season. This might have incremented IVDMD by $1.86 \%$ during the dry season. Therefore, the results of this parameter highlight the potential of this species as an alternative during low-precipitation periods, for both biomass production (Morales-Velasco et al., 2016) and steady relative quality.

During the dry season, Tobiatá, Mombasa, Tanzania, Vencedor, Massai, and Coloniao had protein content of 7.09, $6.24,6.13,6.72,7.82$, and $8.30 \%$, respectively. These values were higher than those found in commercial cultivars in important tropical livestock areas (dos Costa et al., 2017; Silva et al., 2017; da Silva et al., 2018). However, in the same research location where this experiment took place, and with a similar number of regrowing days and average height in Massai, Ruiz et al. (2015) showed $14.20 \%$ CP. This could possibly be due to fertilization at establishment and evaluation during the rainy season.

In tropical regions of Colombia, productive differences exist between commercial cultivars and genotypes of the evaluated collection in this research, which could be associated with aspects inherent to morphology (Patiño-Pardo et al., 2018) and nutritional profile. These are advantageous characteristics in terms of adaptation to different livestock systems.

Some studies suggest that in vitro and in vivo digestibility of organic matter increases with the rainy season (Vargas Junior et al., 2013; Silva et al., 2017), and others show that water stress did not significantly affect organic matter digestibility (OMD), (Fariaszewska et al., 2020). The findings in this research suggested that ADF decreased similar to that reported by Larsen et al. (2021) and IVDMD increased slightly during the dry season vis-à-vis the rainy season. This condition might be related to the average height of germplasm of 130.7 vs. $55.2 \mathrm{~cm}$ during the rainy and dry seasons, respectively. Therefore, growth in height could result from a decrease in leaf material and the respective digestibility (Kalmbacher et al., 1980), and drought stress might delay maturity, which can improve the OMD of forages (Fariaszewska et al., 2020). The correlations found in the $M$. maximus collection were similar to those reported by Stabile et al. (2010) with commercial cultivars.

The classification of the accessions under multivariate tests (by cluster analysis and Hotelling's T-squared test) and NCI shows that the genotypic and physical characteristics specific to each accession (not included in this study) as well as morphological aspects (Santos et al., 2010), leaf-to-stem ratio (Homen et al., 2010), and maturity or metabolism rate (dos Costa et al., 2017) may have influenced the classification of materials with a low or high nutritional profile.

This classification shows that some accessions respond to prolonged tropical dry periods and possibly show promise for resilient nutritional quality with adequate DMB. In addition, $M$. maximus outperforms other forage species used for grazing under semiarid or dry tropical conditions (Coêlho et al., 
2018). For a diversity of agronomic parameters and nutritional composition related to genetic aspects, M. maximus shows promise for breeding programs.

Agronomic and nutritional analysis, in general terms, allows us to learn about a large group of Megathyrsus maximus accessions as potential options for the establishment and management of productive and efficient cattle raising under the agro ecological conditions of the Patía Valley, thus, contributing to the agricultural development of the region and the quality of life of its producers.

The $M$. maximus collection contains several materials that stand out for their nutritional value (CP, NDF, ADF, and IVDMD), which, although they did not show a relationship with DMB, have sufficient productive yield. They also have adaptation potential for drought or low-rainfall conditions in tropical regions. Therefore, they represent a suitable option for sustainable livestock systems. Furthermore, they help subsequent plant breeding programs to contribute to finding alternative materials to maintain adequate feeding efficiency for cattle and mitigate the effects of climate change.

Both the genotypic characteristics of $M$. maximus and environmental conditions during contrasting seasons are factors that might influence the variability of nutritional content, productive parameters, and flowering of the evaluated germplasm. This allows a classification of forage material according to specific or preferential criteria of farmers and plant breeders.

\section{DATA AVAILABILITY STATEMENT}

The original contributions presented in the study are included in the article/Supplementary Material, further inquiries can be directed to the corresponding author.

\section{REFERENCES}

AOAC International (2002). AOAC Official Method 2001.11 Protein (Crude) in Animal Feed, Forage (Plant Tissue), Grain, and Oilseeds. Rockville, MD: AOAC International. Available online at: http://www.eoma.aoac.org/methods/ info.asp?ID \$=\$32924 (accessed March 15, 2020).

Atencio Solano, L., Tapia Coronado, J. J., Barragán Hernández, W., Mojica Rodriguez, J. E., Suárez, E., Martínez, A., et al. (2018). Cultivar de pasto Guinea (Megathyrsus maximus) Gramínea forrajera de alta producción de forraje, excelente calidad nutricional y abundante producción de semilla AGROSAVIA. Available online at: https://repository.agrosavia.co/handle/20.500.12324/34646 (accessed October 15, 2019).

Barahona-Rosales, R., and Sánchez-Pinzón, S. (2005). Physical and chemical limitations to the digestibility of tropical forages and strategies to overcome them. Dialnet 6, 69-82. doi: 10.21930/rcta.vol6_num1_art:39

Barragán-Hernández, W. A., and Cajas-Girón, Y. S. (2019). Bromatological and structural changes in Megathyrsus maximus in four silvopastoral arrangement systems. Corpoica Cienc. Tecnol. Agropecu. 20, 245-258. doi: 10.21930/rcta.vol20_num2_art:1458

Benabderrahim, M. A., and Elfalleh, W. (2021). Forage potential of non-native guinea grass in North African agroecosystems: genetic, agronomic, and adaptive traits. Agronomy 11:1071. doi: 10.3390/agronomy11061071

Braz, D. S. T. G., Martuscello, J. A., Jank, L., da Fonseca, D. M., Resende, M. D. V., and Evaristo, A. B. (2017). Genotypic value in hybrid progenies of

\section{AUTHOR CONTRIBUTIONS}

JC-T carried out the experimental work, statistical analyses, wrote the manuscript, the original draft, and the methodology. JM performed the experiment based on NIRS Technology. NV-Q handled the supervision, the project administration, the acquisition of funds, helped on the conceptualization, validation, and the writing of the original draft. All authors contributed to the analysis and interpretation of data.

\section{ACKNOWLEDGMENTS}

The authors express their gratitude for the contributions to this study to the National Open and Distance University of Colombia-UNAD, the Government of Cauca; the Colombian General System of Royalties (SGR); the Universidad del Cauca and its School of Agricultural Sciences, its Research Group NUTRIFACA, and the Cooperative of Producers from Patía Valley (COOAGROUSUARIOS-Cooperativa de Usuarios Campesinos del Patia-Peasant Users Cooperative of the Patia Valley). This research was conducted as part of the CGIAR Research Program on Livestock and is supported by contributors to the CGIAR Trust Fund. CGIAR is a global research partnership for a food-secure future. Its science is carried out by 15 Research Centers in close collaboration with hundreds of partners across the (globe. www.cgiar.org).

\section{SUPPLEMENTARY MATERIAL}

The Supplementary Material for this article can be found online at: https://www.frontiersin.org/articles/10.3389/fsufs. 2021.684747/full\#supplementary-material

Panicum maximum Jacq. Ciência Rural 47, 1-6. doi: 10.1590/0103-8478cr201 60599

Carvajal-Tapia, J., Morales Velasco, S., Villegas, D. M., Arango, J., and Vivas Quila, N. J. (2021). Biological nitrification inhibition and forage productivity of Megathyrsus maximus in Colombian dry tropics. Plant Soil Environ 5, 270-277. doi: $10.17221 / 445 / 2020$-PSE

Carvalho, S. A. L., Martuscello, J. A., de Almeida, O. G., dos Santos Braz, T. G., DaCunha, D. D. N., and Jank, L. (2017). Production and quality of Mombaça grass forage under different residual heights. Acta Scientiarum. Animal Sci. 39:143. doi: 10.4025/actascianimsci.v39i2.34599

Casler, M. D. (2019). Selection for flowering time as a mechanism to increase biomass yield of upland switchgrass. Bioenergy Res. 13, 100-108. doi: 10.1007/s12155-019-10044-3

Casler, M. D., Vogel, K. P., Lee, D. K., Mitchell, R. B., Adler, P. R., Sulc, R. M., et al. (2018). 30 years of progress toward increased biomass yield of switchgrass and big bluestem. Crop Sci. 58, 1242-1254. doi: 10.2135/cropsci2017.12.0729

Castañeda, L., Olivera, Y., and Wencomo, H. B. (2015). Selection of Pennisetum purpureum accessions for livestock feeding systems. Pastos y Forrajes, 38, 170-175. Available online at: http://scielo.sld.cu/pdf/pyf/v38n2/pyf03215. pdf

Coêlho, J. J., de Mello, A. C. L., dos Santos, M. V. F., Dubeux Junior, J. C. B., da Cunha, M. V., Lira, M., et al. (2018). Prediction of the nutritional value of grass species in the semiarid region by repeatability analysis. Pesqui. Agropecu. Bras. 53, 378-385. doi: 10.1590/s0100-204x2018000300013 
Contreras, I., Hinojosa, M. A., and Mármol, A. (2004). Multicriteria weighted indices with ordinal information. Estadística Española 46, 95-117. Available online at: https://dialnet.unirioja.es/servlet/articulo?codigo $=831086$

Cook, B. G., and Schultze-Kraft, R. (2015). Botanical name changes: nuisance or a quest for precision? Trop. Grassl. 3, 34-40. doi: 10.17138/TGFT(3)34-40

Cooke, R. F., Daigle, C. L., Moriel, P., Smith, S. B., Tedeschi, L. O., and Vendramini, J. M. B. (2020). Cattle adapted to tropical and subtropical environments: social, nutritional, and carcass quality considerations. J. Anim. Sci. 98:skaa014. doi: 10.1093/jas/skaa014

da Silva, A. B., de Carvalho, C. A. B., Morenz, D. A., da Silva, P. H. F., dos Santos, A. J., Santos, F. C., et al. (2018). Agricultural answers and chemical composition of Massai grass under different nitrogen doses and urea sources. Semina: Ciênc. Agrár. 39:1225. doi: 10.5433/1679-0359.2018v39n3p1225

de Vasconcelos, A. M., Dutra, M. C. A., Silveira, R. M. F., da Silva, V. J., Nunes, L. A. P. L., and Ferreira, J. B. (2019). Production and nutritive value of canarana erecta lisa (Echinocloa piramidalis Lam.) in response to harvest intervals. Ciênc. Anim. Bras. 20, 1-11. doi: 10.1590/1809-6891v20e-52300

Dele, P., Akinyemi, B., Amole, T., Okukenu, O., Sangodele, O., Sosande, O., et al. (2017). Effect of manure type and season of harvest on the forage yield, quality and macro-elements of two Panicum maximum varieties. Niger. J. Anim. Sci. 19, 265-282. Available online at: https://www.ajol.info/index.php/tjas/article/ view/163832

Deo, T. G., Ferreira, R. C. U., Lara, L. A. C., Moraes, A. C. L., Alves-Pereira, A., de Oliveira, F. A., et al. (2020). High-resolution linkage map with allele dosage allows the identification of regions governing complex traits and apospory in guinea grass (Megathyrsus maximus). Front. Plant Sci. 11:15. doi: $10.3389 /$ fpls. 2020.00015

dos Costa, C. S., Rodrigues, R. C., de Araújo, R. A., Cândido, M. J. D., Santos, F. N., et al. (2017). Agronomic and nutritional characteristics of Massai grass subjected to deferred grazing and nitrogen fertilization. Semin. Cienc. Agrar. 38, 1617-1624. doi: 10.5433/1679-0359.2017v38n3p1607

Fariaszewska, A., Aper, J., Van Huylenbroeck, J., De Swaef, T., Baert, J., and Pecio, L. (2020). Physiological and biochemical responses of forage grass varieties to mild drought stress under field conditions. Int. J. Plant Prod. 14, 335-353. doi: 10.1007/s42106-020-00088-3

Gándara, L., Borrajo, C., Fernández, J., and Pereira, M. (2017). Efecto de la fertilización nitrogenada y la edad del rebrote sobre el valor nutritivo de Brachiaria brizantha cv. Marandú. Rev. FCA UNCUYO 49, 69-77. Available online at: https://www.redalyc.org/articulo.oa?id=382852189006

Gaviria, X., Naranjo, J. F., and Barahona, R. (2015). Cinética de fermentación in vitro de Leucaena leucocephala y Megathyrsus maximus y sus mezclas, con o sin suplementación energética. Pastos y Forrajes 38, 55-63. Available online at: http://scielo.sld.cu/scielo.php?script=sci_arttext\&pid=S086403942015000100006

Gerber, P. J., Mottet, A., Opio, C. I., Falcucci, A., and Teillard, F. (2015). Environmental impacts of beef production: review of challenges and perspectives for durability. Meat Sci. 109, 2-12. doi: 10.1016/j.meatsci.2015.05.013

Gusha, J., Halimani, T. E., Ngongoni, N. T., Masocha, M., Katsande, S., and Mugabe, P. H. (2019). Effect of growth stage and method of conservation of $H$. filipendula and $H$. dissoluta on nutrient composition and digestibility. Trop. Subtrop. Agroecosyst. 22, 71-77. Available online at: https://www.revista.ccba. uady.mx/ojs/index.php/TSA/article/view/2693/1217

Hare, M. D., Phengphet, S., Songsiri, T., and Sutin, N. (2015). Effect of nitrogen on yield and quality of Panicum maximum cvv. Mombasa and Tanzania in Northeast Thailand. Trop. Grassl. 3:27. doi: 10.17138/TGFT(3) 27-33

Homen, M., Entrena, I., Arriojas, L., and Ramia, M. (2010). Biomasa y valor nutritivo del pasto Guinea Megathyrsus maximus (Jacq.) BK Simon and S:W:L Jacobs Gamelote en diferentes periodos del año en la zona de bosque húmedo tropical, Barlovento estado Miranda. Zootec. Trop. 28, 255-265. Available online at: http://ve.scielo.org/pdf/zt/v28n2/art11.pdf

ISO 12099:2017. (2017). Animal Feeding Stuffs, Cereals and Milled Cereal Products-Guidelines for the Application of Near Infrared Spectrometry. Available online at: https://www.iso.org/obp/ui/\#iso:std:iso:12099:ed-2:v1:en (accessed December 15, 2019).

Jung, H. G., Mertens, D. R., and Payne, A. J. (1997). Correlation of acid detergent lignin and klason lignin with digestibility of forage dry matter and neutral detergent fiber. J. Dairy Sci. 80, 1622-1628. doi: 10.3168/jds.S0022-0302(97)76093-4

Kalmbacher, R., Hodges, E., and Martin, F. (1980). Effect of plant height and cutting height on yield and quality of Indigofera hirsuta. Trop. Grassl. 14, 14-18.

Kassambara, A., and Mundt, F. (2020). Factoextra: Extract and Visualize the Results of Multivariate Data Analyses. R package version 1.0.7. Available online at: https://CRAN.R-project.org/package=factoextra (accessed September 09, 2021).

Kissmann, K., and Groth, D. (1995). Plantas infestantes e nocivas. In Tomo 3. Available online at: http://www.sidalc.net/cgi-bin/wxis.exe/?IsisScript=agrissa. xisandmethod $=$ postandformato $=2$ and cantidad $=1$ andexpresion $=\mathrm{mfn}=003492$ (accessed December 12, 2018).

Larsen, R. E., Shapero, M. W. K., Striby, K., Althouse, L. D., Meade, D. E., Brown, K., et al. (2021). Forage quantity and quality dynamics due to weathering over the dry season on California annual rangelands. Rangel. Ecol. Manag. 76, 150-156. doi: 10.1016/j.rama.2021.02.010

Lemos, S. N. L., Rodrigues Cavlcante, A. C., Freire Da Silva, T., Macedo Pezzopane, J. R., Santos, P. M., and Duarte Candido, M. J. (2017). Agro-climatic suitability and water requirement for Tanzania guineagrass cultivation in the state of Ceará. Rev. Caatinga 30, 1028-1038. doi: 10.1590/1983-21252017v30n424rc

Macedo, V., Quadros Cunha, A., Cândido, E. P., Domingues, F. N., Melo, D., de, M., et al. (2017). Estructura e productividade de Campim-Tanzania submetido a diferentes frquencias de desfolhacao. Ciênc. Anim. Bras. 18, 1-10. doi: 10.1590/1089-6891v18e-38984

Machado, R. (2013). Comportamiento de 19 accesiones de Panicum maximum Jacq. bajo condiciones de pastoreo en un suelo de mediana fertilidad. Pastos y Forrajes, 36, 202-208. Available online at: http://ve.scielo.org/scielo.php? script=sci_arttext\&pid=S0798-72692010000200012\&lng=es\&nrm=iso

Maranhão, S. R., Franco Pompeu, R. C. F., de Araújo, R. A., Lopes, M. N., Duarte Cândido, M. J., de Souza, H. A., et al. (2021). Morphophysiology of tropical grasses under different water supply in two growing seasons: II. BRS Massai and BRS Tamani grasses. Semina: Cienc. Agrar. 42, 301-318. doi: 10.5433/1679-0359.2021v42n1p301

Marcillo, R. L. G., Guamàn, W. E. C., Pincay, A. E. G., Zambrano, P. A. V., Naveda, N. R. O., and Rivera, S. A. G. (2021). Assessment of guinea grass Panicum maximum under silvopastoral systems in combination with two management systems in Orellana Province, Ecuador. Agriculture 11:117. doi: 10.3390/agriculture11020117

Matínez-Mamian, C., Vivas-Quila, N. J., and Morales-Velasco, S. (2020). Agronomic response of forage mixtures in a silvopastoral system in the Colombian dry tropics. Dyna 87, 80-84. doi: 10.15446/dyna.v87n213.79900

Mazabel, J., Worthington, M., Castiblanco, V., Peters, M., and Arango, J. (2020). Using near infrared reflectance spectroscopy for estimating nutritional quality of Brachiaria humidicola in breeding selections. Agrosyst. Geosci. Environ. 3, 1-9. doi: 10.1002/agg2.20070

Molano, M. L., Cortés, M. L., Ávila, P., Martens, S. D., and Muñoz, L. S. (2016). Ecuaciones de calibración en espectroscopía de reflectancia en el infrarrojo cercano (NIRS) para predicción de parámetros nutritivos en forrajes tropicales. Trop. Grassl. 4:139. doi: 10.17138/TGFT(4)139-145

Morales-Vallecilla, F., and Ortiz-Grisales, S. (2018). Productivity and efficiency of specialized dairy farms in the Valley of Cauca (Colombia). Rev. de la Facultad de Med. Vet. $y$ de Zootec. 65, 252-268. doi: 10.15446/rfmvz.v65n3.76463

Morales-Velasco, S., Vivas-Quila, N. J., and Teran-Gómez, V. F. (2016). Ganadería eco-eficiente y la adaptación al cambio climático. Biotecnol. en el Sector Agropecuario y Agroind. 14, 135-144. doi: 10.18684/BSAA(14)135-144

Mwendia, S. W., Maass, B., Njenga, D., and Notenbaert, A. (2019). Perennial ryegrass and novel festulolium forage grasses in the tropical highlands of Central Kenya: preliminary assessment. Trop. Grassl. 7, 234-243. doi: $10.17138 / \operatorname{tgft}(7) 234-243$

Parrini, S., Acciaioli, A., Crovetti, A., and Bozzi, R. (2018). Use of FT-NIRS for determination of chemical components and nutritional value of natural pasture. Ital. J. Anim. Sci. 17, 87-91. doi: 10.1080/1828051X.2017.1345659

Patiño-Pardo, R., Gómez-Salcedo, R., and Navarro-Mejía, O. (2018). Nutritional quality of Mombasa and Tanzania (Megathyrsus maximus Jacq.) managed at different frequencies and cutting heights in Sucre, Colombia. Rev. CES Med. Vet. y Zootec. 13, 17-30. doi: 10.21615/cesmvz.13.1.2

Paul, B. K., Koge, J., Maass, B. L., Notenbaert, A., Peters, M., Groot, J. C. J., et al. (2020). Tropical forage technologies can deliver multiple benefits 
in Sub-Saharan Africa. A meta-analysis. Agron. Sustain. Dev. 40, 1-17. doi: 10.1007/s,13593-020-00626-3

R Core Team (2020). R: A Language and Environment for Statistical Computing. Vienna: R Foundation for Statistical Computing.

Ramakrishnan, P., Babu, C., and Iyanar, K. (2014). Genetic diversity in Guinea grass (Panicum maximum Jacq.) for fodder yield and quality using morphological markers. Int. J. Plant Biol. Res. 2:1006. Available online at: https://www.jscimedcentral.com/PlantBiology/plantbiology-2-1006.pdf

Rao, I. (2013). "Advances in improving adaptation of common bean and Brachiaria Forage Grasses to abiotic stresses in the tropics," in Handbook of Plant and Crop Physiology, ed P. Mohammad (Boca Raton, FL: CRC), 847-889. doi: 10.1201/b16675-49

Rodríguez, M., Amaro, O., Machado-Martínez, H., and Machado-Castro, R. (2017). Megathyrsus maximus. Resultados científicos y potencialidades ante el cambio climático en el trópico. Av. Investig. Agropecu. 21, 41-61. Available online at: http://ww.ucol.mx/revaia/portal/pdf/2017/sept/4.pdf

Ruiz, F., Rodriguez, E., Pinzón, J., Anzola, H., and Castro, L. (2015). Establecimiento y evaluación del guinea Panicum máximum cv Massai en la hacienda Guachicono del Bordo, Patía (Cauca). Rev. Ciencia Anim. 9, 125-154.

Santiago-Hernández, F., López-Ortiz, S., Ávila-Reséndiz, C., Jarillo-Rodríguez, J., Pérez-Hernández, P., and de Dios Guerrero-Rodríguez, J. (2016). Physiological and production responses of four grasses from the genera Urochloa and Megathyrsus to shade from Melia azedarach L. Agrofor. Syst. 90, 339-349. doi: 10.1007/s10457-015-9858-y

Santos, M. E. R., Miranda Da Fonseca, D., Márcio Balbino, E., Pedro Da Silva, S., Ismério, J. P., and Monnerat, S. (2010). Valor nutritivo de perfilhos e componentes morfológicos em pastos de capim-braquiária diferidos e adubados com nitrogênio. Rev. Bras. Zootec. 39, 1919-1927. doi: 10.1590/S1516-35982010000900009

SAS (2016). SAS Institute Inc., Version 9.4. Software 9.4 (TS1M5). Cary, NC: SAS.

Schafer, J., Opgen-Rhein, R., Zuber, V., Ahdesmaki, M., Silva, A. P. D., and Strimmer, K. (2017). Corpcor: Efficient Estimation of Covariance and (Partial) Correlation. $R$ Package Version 1.6.9. Available online at: https://CRAN.Rproject.org/package $=$ corpcor $($ accessed September 09, 2021).

Schnellmann, L. P., Verdoljak, J. J. O., Bernardis, A., Martínez-González, J. C., Castillo-Rodríguez, S. P., and Limas-Martínez, A. G. (2020). Cutting frequency and height on the quality of Megathyrsus maximus (cv. Gatton panic). Corpoica Cienc. Tecnol. Agropecu. 21:e1402. doi: 10.21930/rcta.vol21_num3_art:1402

Silva, T. V. S., Sousa, L. F., Santos, A. C., dos, Ferreira, A. C. H., Cardoso, R. R., Sousa, J. T. L., et al. (2017). Nutritional quality of massai grass fertilized with phosphorus and nitrogen and its influence on intake and weight gain of sheep under rotational grazing on quartzipsamment soil. Semina: Ciênc. Agrár. 38:1427. doi: 10.5433/1679-0359.2017v38n3p1417

Soares Filho, C. V., Cecato, U., Ribeiro, O. L., Roma, C. F., da, C., and Beloni, T. (2015). Morphogenesis in pastures with Tanzania grass fertilized with nitrogen doses under a grazing system. Acta Sci.-Anim. Sci. 37:235. doi: 10.4025/actascianimsci.v37i3.27101

Stabile, S., dos, S., Salazar, D. R., Jank, L., Renn, F. P., and Silva, L. F. P. e. (2010). Características de produçao e qualidade nutricional de genoipos de capim-coloniao colhidos em tres estádios de maturidade. Rev. Bras. Zootec. 39, 1418-1428. doi: 10.1590/S1516-35982010000700004

Tavares de Castro, C. R., and Carvalho, M. M. (2000). Florescimento de gramíneas forrageiras cultivadas sob luminosidade reduzida. Cienc. Rural 30, 163-166. doi: 10.1590/S0103-84782000000100026

Tesk, C. R. M., Cavalli, J., Pina, D. S., Pereira, D. H., Pedreira, C. G. S., Jank, L., et al. (2020). Herbage responses of Tamani and Quênia guineagrasses to grazing intensity. Agron. J. 112, 2081-2091. doi: 10.1002/agj2.20189
Tilley, J. M., and Terry, R. (1963). A two stage technique for the in vitro digestión of forage crops. (British Gr). Grass Forage Sci. 18, 104-111. doi: 10.1111/j.1365-2494.1963.tb00335.x

Toledo, J., and Schultze-Kraft, R. (1982). "Metodología para la evaluación agronómica de pastos tropicales," in Manual para la evaluación agronómica, Red Internacional de Evaluación de Pastos Tropicales, ed M. Toledo (Cali: CIAT), 91-116.

Valente, B. S. M., Cândido, M. J. D., Junior, J. A. A. C., Pereira, E. S., Bomfim, M. A. D., and Feitosa, J. V. (2010). Chemical composition, digestibility and in situ degradation of sheep diet on Tanzania grass with three defoliation frequencies. Rev. Bras. Zootec. 39, 113-120. doi: 10.1590/S1516-35982010000 100015

Van Soest, P. (1982). Nutritional Ecology of the Ruminant. Ithaca, NY: Cornell University Press.

Van Soest, P., Robertson, J., and Lewis, B. (1991). Methods for dietary fiber, neutral detergent fiber, and non-starch polysaccharides in relation to animal nutrition. Dairy Sci. 74, 3583-3597. doi: 10.3168/jds.S0022-0302(91)78551-2

Vargas Junior, F. M., Socorro, M. M., de Setti, J. C. A., Pinto, G. S., Martins, C. F., et al. (2013). Disponibilidade e valor nutritivo de gramíneas tropicais sob pastejo com ovinos. Arch. Zootec. 62, 295-298. doi: 10.4321/S0004-05922013000200016

Velásquez, P. A. T., Berchielli, T. T., Reis, R. A., Rivera, A. R., Dian, P. H. M., Teixeira, I. A. M., et al. (2010). Composição química, fracionamento de carboidratos e proteínas e digestibilidade in vitro de forrageiras tropicais em diferentes idades de corte. Rev. Bras. Zootec. 39, 1206-1213. doi: 10.1590/S1516-35982010000600007

Vivas-Quila, N. J., Carrillo, S., Galindez, J., Morales-Velasco, S., Gutierrez-Solis, J. F., and Peters, M. (2015). "Evaluation of the establishment of livestock feed association for tropical American system ID310 in Pastoralism and forage systems," in Posters 239 (Bonn).

Wei, T., and Simko, V. (2017). R Package "corrplot": Visualization of a Correlation Matrix (Version 0.84). Available online at: https://github.com/taiyun/corrplot (accessed September 09, 2021).

Wickham, H. (2016). ggplot2: Elegant Graphics for Data Analysis. New York, NY: Springer-Verlag. doi: 10.1007/978-3-319-24277-4_9

Wilson, J., and $\mathrm{Ng}$, T. (1975). Influence of water stress on parameters associated with herbage quality of Panicum maximum var. trichoglume. Aust. J. Agric. Res. 26, 127-136. doi: 10.1071/AR9750127

Conflict of Interest: The authors declare that the research was conducted in the absence of any commercial or financial relationships that could be construed as a potential conflict of interest.

Publisher's Note: All claims expressed in this article are solely those of the authors and do not necessarily represent those of their affiliated organizations, or those of the publisher, the editors and the reviewers. Any product that may be evaluated in this article, or claim that may be made by its manufacturer, is not guaranteed or endorsed by the publisher.

Copyright (C) 2021 Carvajal-Tapia, Mazabel and Vivas-Quila. This is an open-access article distributed under the terms of the Creative Commons Attribution License (CC $B Y)$. The use, distribution or reproduction in other forums is permitted, provided the original author(s) and the copyright owner(s) are credited and that the original publication in this journal is cited, in accordance with accepted academic practice. No use, distribution or reproduction is permitted which does not comply with these terms. 